\title{
Összefüggés a népesség növekedése és az urbanizáció között
}

\section{Relationship between Population Growth and Urbanization}

\author{
N. NoVÁK
}

Debreceni Egyetem, Gazdaságtudományi Kar, Vidékfejlesztés, Regionális gazdaságtan Tanszék, Debreceni Egyetem, Ihrig Károly Gazdálkodás- és Szervezéstudományok Doktori Iskola novak.norbert@econ.unideb.hu

Absztrakt. Jelen cikk fó célja, hogy megvizsgáljam milyen trendek indultak el az urbanizáció terén, illetve hogy miként hat ez a vidékre és az életszínvonal változására. A globalizáció, az új ágazatok megjelenése és a hagyományos mezőgazdasági dominancia csökkenése új lehetőségeket és kihívásokat teremt. A városi és vidéki környezet változó tendenciáihoz hasonlóan az emberek preferenciái is nagyon változatosak, életük során változhatnak. A nagyváros és a kisváros közötti különbség eltérő életmódot tesz lehetővé. Alapvetően hasonló infrastrukturális lehetőségekkel rendelkeznek (mindkettő város), de a nagyobb városok mennyiségi és minőségi szempontból nagyon különböznek a kisvárosoktól. A kisvárosok előnye lehet például a nyugodtabb és egészségesebb életmód, de ez nem feltétlenül igaz minden tekintetben. A fejlődő és fejlett országok urbanizációjának eltérő tulajdonságai között az eltérő időbeli lefutást és az eltérő nagyságrendet is említhetjük [1]. A fejlett országokban ugyanis hosszú idő alatt és kevesebb embert érintve zajlott a városrobbanás szakasza, mint a fejlődőkben [2]. Városi népességnövekedés üteme az utóbbi csoportban 1950 és 1975 között 4,04\%, 1975 és 2000 között 3,6\%, 2000 és 2030 között pedig várhatóan 2,4\% lesz. A Föld és az egész emberiség manapság számos kihívással néz szembe, és ez a tendencia a jövőben is folytatódni fog. A bolygó túlnépesedése és a változó étkezési szokások nagy nyomást gyakorolnak a mezőgazdaságra és a vidékre is. A vidékre összpontosító kutatások többnyire a vidéki térségek különféle funkcióinak elemzésére irányulnak.

Abstract. The main purpose of this article is to examine how to respond to and change the field of urbanization. Creating dwindling new opportunities and challenges for globalization, new sector introductions and agricultural dominance. In relation to changing trends in urban and rural environments, people's preferences are very diverse and their lives are changing. The difference between a big city and a small city can test different lifestyles. It is a fundamentally important infrastructure personality insurance system (both cities), important from the point of view of larger cities and very different from small towns in terms of quality. The benefits of small towns can be a unique lifestyle and a healthy lifestyle, which can certainly be felt. Among the different characteristics of urbanization in developing and developed countries, we can mention the different time course and magnitude [1]. Namely, in developed countries the urban explosion has taken place for a long time and with fewer people than in developing countries [2]. The rate of urban population growth in the latter group will be 4.04\% between 1950 and 1975, 3.6\% between 1975 and 2000, and 2.4\% between 2000 and 2030. The Earth and all of humanity are facing many challenges these days, and this trend will continue in the future. The planet's overpopulation and changing eating habits put great pressure on agriculture and the countryside. Research focused on the countryside focuses on analyzing the various functions of rural areas. 


\section{Bevezetés}

Az ember, mint biológiai lény, mozgásra született. Az emberi életmód változásai miatt a mozgásigény jelentősen megváltozott napjainkra, a korábbiakhoz képest lecsökkent. Ezzel párhuzamosan megjelentek a civilizációs betegségek is, melyek létét kutatások támasztják alá. A mai életben az emberek használják a kényelmi eszközöket és nem gondolják át, hogy ennek milyen káros következményei vannak a saját egészségükre nézve. „Korunk vívmánya az átlagéletkor növekedése, így egyre nagyobb a jelentősége az egészség megőrzésének, megtartásának és az egészségben eltöltött életévek növelésének" [3, pp 3.].

Az ENSZ 1988 óta készít külön becslést a népesség országon belüli területi elhelyezkedésére, a városi és vidéki, valamint a nagyvárosi agglomerációk lakosságára vonatkozóan. 2018 májusában tették közzé a világ urbanizációs folyamatának 2050-ig szóló legfrissebb számításait, amely az előzőekben ismertetett, 2017. évi ENSZ népesség-előrejelzés bázisán készült. A világ urbanizációs folyamataira vonatkozó információk elengedhetetlenek a településfejlesztési célok meghatározásához a városi és a vidéki területeken egyaránt. A városi népesség arányát a gazdasági-társadalmi fejlődés egyik alapmutatójának tekintik. Ezért az urbanizáció időbeli és térbeli növekedése jól jelzi a fejlődés alakulását. A városiasodás folyamata a városok számának gyarapodásával, valamint lélekszámuk növekedésével jellemezhető. 1950-ben a világ népességének még kevesebb mint 30\%-a élt városokban. 2010-re a városlakók száma már meghaladta a vidéki lakosokét. 2018-ban a népesség 55\%-a városi térségekben lakik. A világ városlakóinak összlétszáma az 1950. évi 751 millióról napjainkra közel 4,2 milliárdra (5,6szeresére), a vidéki népesség 3,4 milliárdra (mindössze a duplájára) növekedett (1. ábra) [4].

- A világ vidéki lakossága 1950 óta lassan nőtt, és várhatóan néhány év alatt eléri a maximumot.

- A globális vidéki népesség ma már közel 3,4 milliárd, 2050-ig várhatóan enyhén emelkedik, majd 3,1 milliárdra csökken. Afrikában és Ázsiában él a világ vidéki lakosságának közel 90\%-a.

- Indiában lakik a legnagyobb létszámú vidéki népesség (893 millió fô), ezt követi Kína (578 millió fő).

- A világ városi lakossága 1950 óta gyorsan növekedett, és 2018-ra 751 millióról 4,2 milliárdra nőtt.

- Ázsia, annak ellenére, hogy kevésbé urbanizált, mint a legtöbb más régió, a világ városi lakosságának 54\%-át adja, ezt követi Európa és Afrika (mindegyik 13\%) (1. ábra) [5]. 


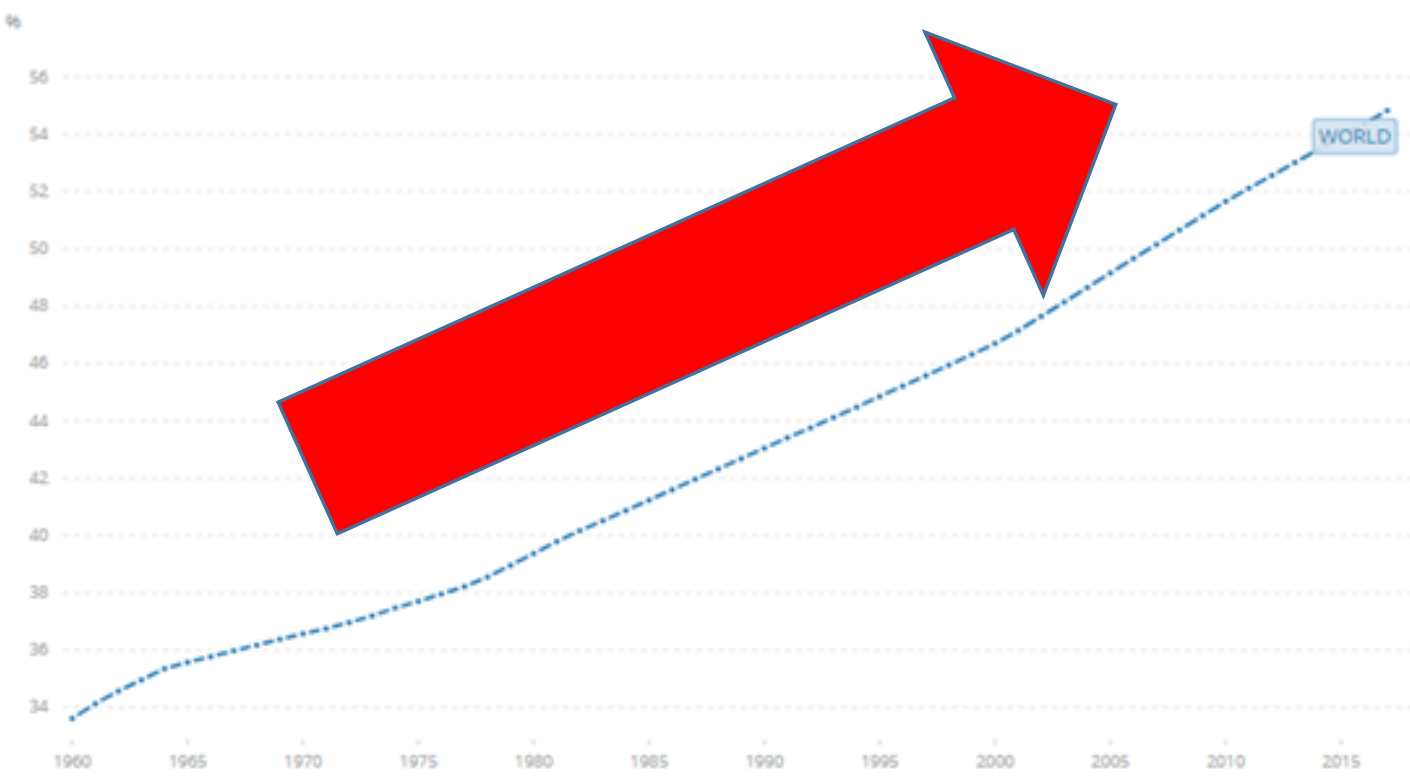

1. ábra: Világ városi lakosságának a növekedése a globális népesség százalékában (1960-2018) (\%)

Forrás: [5] alapján, Saját szerkesztés (2019)

Anyag és módszer

A tanulmány publikációkon alapul, amelyek a vidék szerepének fontosságát vizsgálják a kutatási terület gazdasági és társadalmi szempontjai szerint, továbbá vizsgálja az aktuális trendeket is. Az elemzéshez nemzetközi kutatásokat, jelentéseket és tudományos publikációkat használtam, amelyek szorosan kapcsolódnak a kutatási területhez. Az elemzések készítése során megvizsgáltam a vidéki térségek szerepét napjaink urbanizációs trendjeiben, illetve az egészségtudatosságban annak érdekében, hogy rámutathassak a vidéki területek fontosságára és az egészséges élethez való hozzájárulásukra. Egyre növekszik azon szakirodalmak száma, amelyek a vidék egészségmegőrzésben betöltött szerepével foglalkoznak.

A statisztikai adatok és jelentések összegyüjtése során a KSH, az EUROSTAT online adatbázisát használtam. Cikkeket és tanulmányokat gyűjtöttem a GOOGLE SCHOLAR, az AGECONSEARCH és a GOOGLE.COM adatbázisaiból.

\section{Szakirodalmi áttekintés}

Az EU-28 lakosságának csupán egynegyede (28,0\%) élt vidéki térségben 2015-ben, némileg nagyobb arányt képviseltek a városokban és külvárosokban (31,6\%) élő polgárok, míg az EU 28ban a lakosság legnagyobb része városokban él (40,4\%). A 2010-től 2015-ig tartó ötéves időszakban fokozatosan nőtt a vidéki területeken élő emberek száma. Az EU tagállamai között jelentős különbségek voltak a vidéki lakosságuk relatív méretével kapcsolatban: Litvánia volt az egyetlen ország, ahol a lakosság többsége (56,2\%) élt vidéki területen [5].

A mezőgazdaság fontos szerepet játszik a vidéki és városi lakosság táplálkozásának biztosításában egyaránt. Ebben a folyamatban a mezőgazdasági termelés folyamatát más termékek és szolgáltatások igénybevételére ösztönzik és a foglalkoztatási lehetőségek kialakulnak a társadalom munkaerő-felvételére. A ciklus kialakulása során a növekvő mezőgazdasági termelés 
növekvő keresletet eredményez az inputok iránt, ez utóbbiak pedig biztosítják a mezőgazdasági termelés fenntartásához szükséges erőforrásokat. A föld a legtöbb ország számára alapvető erőforrás, és ennek az erőforrásnak a polgárok érdekében történő kiaknázása az ország egyik fő feladata. Magyarország régióit vizsgálva a jóllét fogalmába az egészségesség tudatát is beleértjük. A közép-magyarországi jóllét a vizsgálati szempontok több mint felében a legjobb eredményeket mutatja az országban [4].

A globalizáció, az új ágazatok megjelenése és a hagyományos mezőgazdasági dominancia csökkenése új lehetőségeket és kihívásokat teremt. A városi és vidéki környezet változó tendenciáihoz hasonlóan az emberek preferenciái is nagyon változatosak és életük során változhatnak. A nagyváros és a kisváros közötti különbség eltérő életmódot tesz lehetővé. Alapvetően hasonló infrastrukturális lehetőségekkel rendelkeznek (mindkettő város), de a nagyobb városok mennyiségi és minőségi szempontból nagyon különböznek a kisvárosoktól. A kisvárosok előnye lehet például a nyugodtabb és egészségesebb életmód, de ez nem feltétlenül igaz minden tekintetben [4].

Erős összefüggés figyelhető meg a népesség növekedése és az urbanizáció között. A népesség növekedésével a városi népesség aránya folyamatosan emelkedik, hozzájárulva a vidéki területek elnéptelenedéséhez. A globális népesség változásai közvetlen hatással vannak a természeti környezetre is. Kétségtelen, hogy a népesség növekedése a globális változások egyik fő mozgatórugója [4].

A szegénység vagy a társadalmi kirekesztés kockázata az EU keleti és déli tagországainak vidéki területein volt a legnagyobb [6]. Ez különösen igaz Bulgáriában, Romániában és Máltán, ahol a vidéki népesség legalább felét 2015-ben fenyegette a szegénység vagy a társadalmi kirekesztés. Romániában (és Máltán) a vidéki területeken élők kétszer annyira voltak kitéve a szegénység vagy társadalmi kirekesztés kockázatának, mint a városi területeken élők. Ezzel szemben Ausztriában, Hollandiában, Belgiumban, Dániában, Németországban és az Egyesült Királyságban a vidéki lakosság sokkal kevésbé van kitéve a szegénység vagy a társadalmi kirekesztés veszélyének, mint a városi területeken élők [7]. Érdemes kiemelni, hogy a tagállami elemzés jelentős földrajzi megoszlást mutatott: egyrészt a keleti, a déli és a balti tagországokban a szegénység vagy a társadalmi kirekesztés legnagyobb kockázatát általában a vidéki lakosság körében találták; ezzel szemben a legtöbb nyugati és északi tagállamban a szegénység vagy a társadalmi kirekesztés legnagyobb kockázatát általában a városi lakosság esetében lehet megfigyelni [8].

\subsection{Az ipari forradalom jelentősége}

Bár városok már az időszámításunk előtti évezredekben is léteztek, a városi lakosság aránya világszinten a 19. századig korlátozott maradt [9]. Becslések szerint 1780-ban a 100000 főnél népesebb városok száma a Földön nagyjából 100 volt [9]. Ám az ipari forradalomtól kezdve szinte robbanásszerű növekedés indult meg mind a városok, mind pedig a városlakók száma tekintetében. Az iparosodás ugyanis olyan folyamatokat indított el és olyan új feltételeket teremtett az urbanizáció számára, melyek lehetővé tették a városok korábbinál gyorsabb ütemű növekedését. Alapvetően négy ilyen tényezőt, illetve folyamatot különböztethetünk meg, amelyek közül vizsgálatom szempontjából a migráció bír a legnagyobb jelentőséggel. Az ipari forradalom 
ugyanis nagy hatást gyakorolt a társadalmi munkamegosztásra, hiszen a felszabaduló jobbágyság a mezőgazdaságból fokozatosan az ipari szektorba kezdett áramlani, ami térben az erőteljes faluból városba történő migráció formájában jelentkezett [10].

Az elmúlt közel 10000 évben a népességnövekedés üteme ingadozó volt. Az ipari forradalom, valamint az ezzel párhuzamosan az egészségügyben és az orvostudományban elért haladás eredményeként azonban hatalmas különbségek alakultak ki a térségek között. Az 1800-as évek végére a világ népessége elérte vagy meghaladta az egymilliárd főt, manapság azonban Kína önmagában is 1,4 milliárd lakosú [11]. Az ipari forradalom után mindössze 30 év alatt a globális népesség megduplázódott és több mint 3 milliárdra emelkedett (1960). Így elmondható, hogy a 20. században a globális népesség 1,65 milliárdról 6 milliárdra nőtt. 1970-ben csak körülbelül annyi ember élt a világon, mint ma kb. Kína és Oroszország lakossága [12]. A korábbi rendkívül gyors népességnövekedést követően a népesség éves növekedési üteme az elmúlt néhány évtizedben csökkent. 1962-ben a népesség növekedési üteme 2,1\% volt, azóta pedig majdnem a felére esett vissza [13]. Jelenleg a növekedés üteme 1,2\%-os, ami évente valamivel kevesebb, mint 80 millió embert jelent. Az előrejelzések szerint az éves növekedési ráta a 2100-ra várhatóan 0,1\%-ig csökken [14].

\subsection{Napjaink urbanizációs trendjei}

Ha a jelenlegi globális trendek folytatódnak és a népesség növekedési tendenciái nem változnak, 2050-ig további 2,4 milliárd ember él majd a fejlődő országokban: Dél-Ázsia és a Szaharától délre fekvő Afrika várhatóan folyamatos népességnövekedéssel fog szembenézni. A városi területek nagysága várhatóan háromszorosára emelkedik 2000 és 2030 között [15]. Ezekben az urbanizált régiókban a mezőgazdaság kiemelkedő jelentőségű a nemzetgazdaság szempontjából. A világon a legalacsonyabb jövedelmű emberek 75\%-a vidéki területeken él, ahol a mezőgazdaság az elsődleges jövedelemforrás [16]. A fentiek ellenére a lakosság körülbelül 20\%-ának vannak élelmezésbiztonsági problémái [17]. Az urbanizáció egyre több földterületet von ki a mezőgazdasági termelésből, továbbá folyamatosan nyomást gyakorol a jelenlegi földhasználatra és a biodiverzitásra is [18], miközben az emberiség több természeti erőforrást használ fel, mint amennyit a természet újra képes előállítani [19]. Az urbanizáció az életmód és a fogyasztási szokások átalakulásával jár. A jövedelem növekedésével párhuzamosan az urbanizáció felgyorsítja az étrend diverzifikációját a fejlődő országokban. Amíg a gabonafélék és más növények fogyasztása csökkenni fog, addig növekszik a zöldségek, gyümölcsök, hús, tejtermékek és halak fogyasztása. A félig feldolgozott vagy fogyasztásra kész élelmiszerek iránti növekvő kereslet az élelmiszerlánc további koncentrációjához vezet. Amíg a városi népesség aránya növekedni fog, a vidéki térségek továbbra is a szegény emberek többségének otthonául szolgál majd, ahol még az éhség sem ritka jelenség. Jelenleg 0,8 milliárd ember nem képes kielégíteni alapvető élelmiszer- és energiaigényét [20]. Az étkezési szokások gyors változásai szintén kapcsolódnak az urbanizációhoz. Az emberek, akik abbahagyják a mezőgazdasági tevékenységeket, nagy számban városokba költöznek, ahol étkezési szokásaik is megváltoznak. Jelenleg a világ népességének több mint fele már városi és a jövőben arányuk elkerülhetetlenül tovább fog növekedni. Az urbanizáció és a nemzetközi kereskedelem liberalizációja eredményeként a termelés és a fogyasztás földrajzi központjai között egyre növekszik a távolság, 
ami növeli a szállítás, tárolás és hűtés jelentőségét, valamint az áruk kezelésének költségeit [21]. Az élelmiszer- és üzemanyagárak közötti kapcsolat továbbra is fontos kutatási kérdés, és az elmúlt évtizedben a közöttük kialakult összefüggések szorosabbá váltak [22].

\subsection{A világ legnépesebb országai}

Kína és India bolygónk két legnépesebb országa, itt él a világ lakosságának 19 (több mint 1,4 milliárd fő), illetve 18\%-a (közel 1,4 milliárd fő). Ebben a két ázsiai országban külön-külön is többen élnek, mint a három legkisebb lélekszámú földrészen együttvéve. Az előrejelzés alapján továbbra is Kína és India marad a Föld két legnépesebb országa. India lakossága várhatóan 2024re eléri Kínáét, ekkor mindkét ország népessége 1,4 milliárd fő körül lesz, ezt követően India élre tör és várhatóan a 2060-as évek elejére éri el maximális lélekszámát (1,7 milliárd fő). A 2030-as évek elejétől Kína lakossága kismértékben csökkenni kezd (ennek hátterében az 1979-ben bevezetett egygyermekes kínai családpolitika áll). Az országok közül India és Nigéria népességgyarapodása a legintenzívebb, ketten együttesen a világ növekményének közel negyedét adják a 2018-2050 közötti időszakban. Nigéria, napjaink hetedik legnépesebb országa, 2047-re az Egyesült Államokat is megelőzve a Föld harmadik legnépesebb államává léphet elő. A jelenlegi 10 legnépesebb országban él a világ népességének több mint fele, 58\%-a. Közülük öt Ázsiában, kettő Latin-Amerikában, további egy-egy ország Észak-Amerikában, Afrikában és Európában található. 2050-re az európai, illetve az egyik latin-amerikai helyett Afrikából két újabb ország kerül ebbe a körbe. Az előrejelzés időszakának végére pedig már öt afrikai, négy ázsiai és mindössze egy észak-amerikai állam szerepel a tízes rangsorban. A globális növekedés jelentős része mindössze néhány afrikai országnak tulajdonítható (2. ábra) [23] [4].
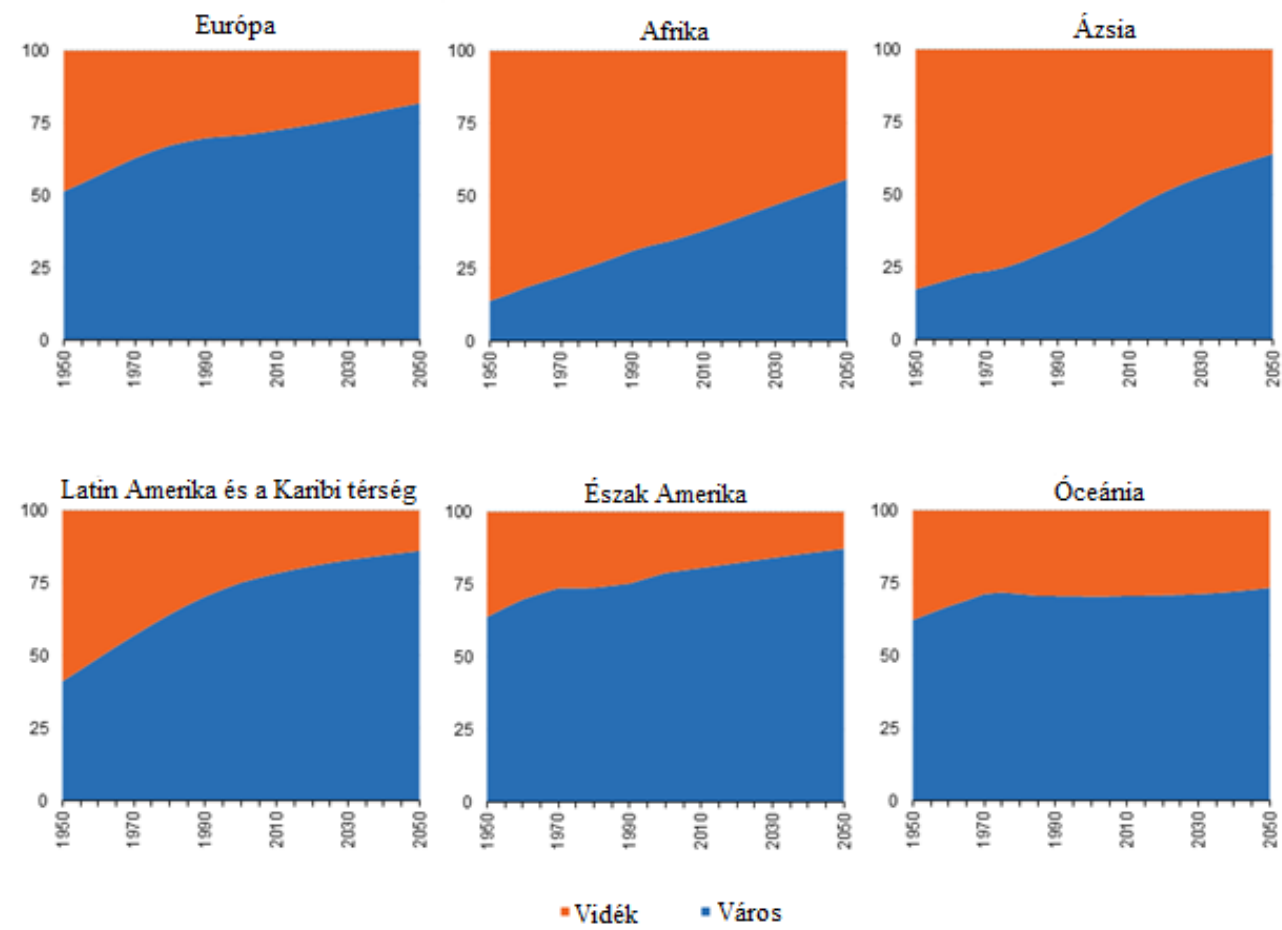

2. ábra: Világ földrészein a városi és vidéki népesség megoszlása (1950-2050) (\%)

Forrás: [7] alapján, Saját szerkesztés (2019) 


\subsection{Európa országainak vizsgálata}

Az EU tagállamai között jelentős különbségek voltak a vidéki lakosságuk relatív méretével kapcsolatban: Litvánia volt az egyetlen ország, ahol a lakosság többsége (56,2\%) élt vidéki területeken (lásd az 3. ábrát), míg a lakosság 45-49\%-a élt Dániában, Horvátországban, Lettországban, Magyarországon, Szlovéniában és Luxemburgban vidéki területen. Ezzel szemben a teljes népesség viszonylag alacsony aránya élt vidéki területeken a legnépesebb tagállamokban, mint például Németországban (22,4\%), Olaszországban (18,9\%), Belgiumban (18,0\%), az Egyesült Királyságban (14,9\%) vagy Hollandiában (14,7\%). Máltán sokkal kisebb arányban $(0,3 \%)$ éltek a vidéki területeken, lakosságának túlnyomó többsége a fővárosban, Vallettában és környékén él. Tehát elmondható, hogy a máltaiak közül 10 lakosból 9-en élnek városban. Az Egyesült Királyságban és Spanyolországban az emberek többsége városokban él. Hasznos figyelembe venni ezeket az eloszlásokat az urbanizáció mértéke szerint, amikor elemezzük az ebben a cikkben bemutatott eredmények fennmaradó részét. Az EU keleti területein fekvő régióinak és a balti tagállamoknak a nagy részét viszonylag nagy vidéki lakosság jellemezte [24].

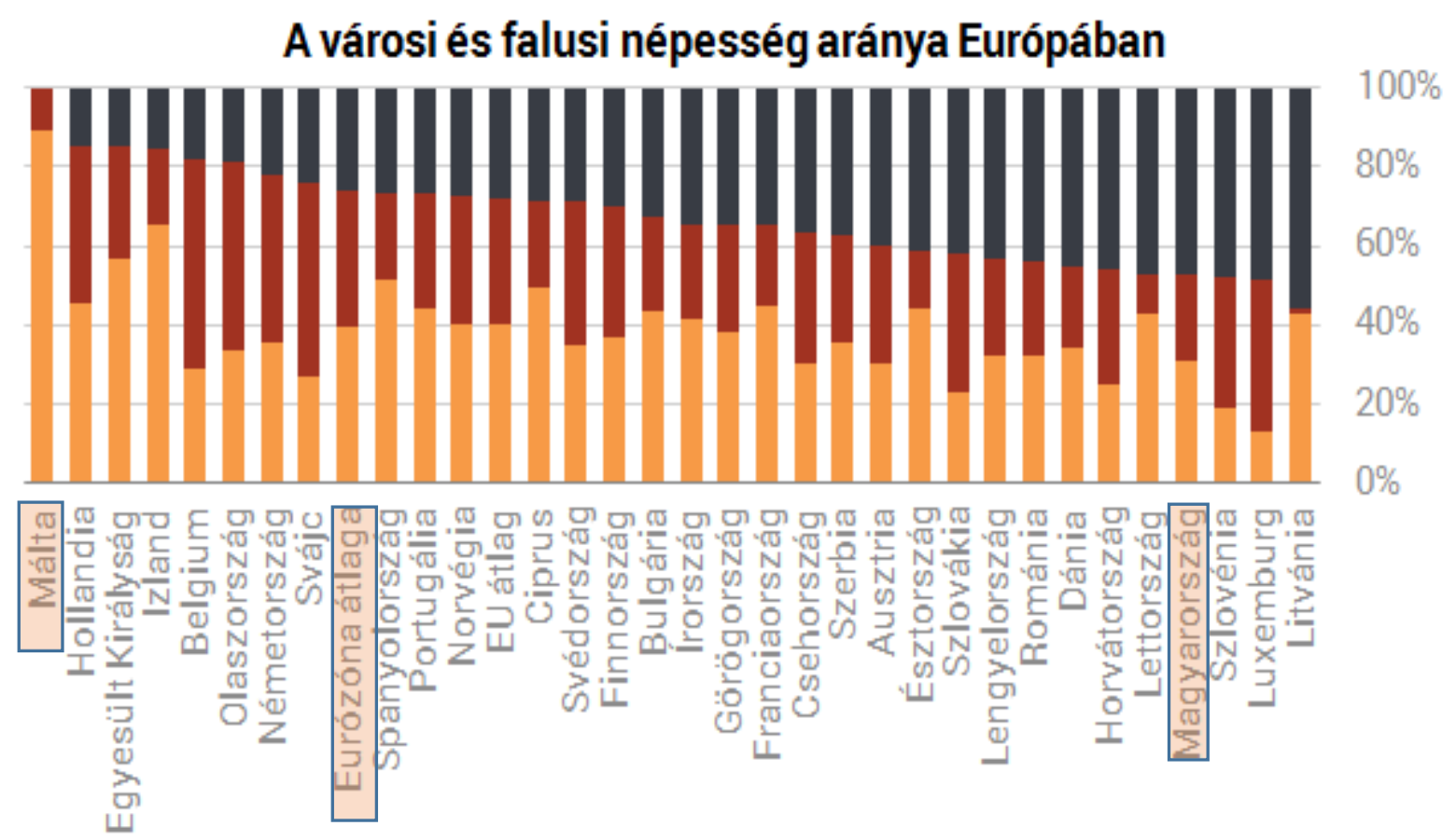

Nagyo b b városban lakók @ Kisvárosban vagy agglomáricóban lakók @ Falvakban élốk

Forrás: Eurostat, Portfolio

\section{3. ábra: A városi és falusi népesség aránya Európában (\%)}

Forrás: [25], saját szerkesztés (2019)

Általánosságban elmondható, hogy az EU globális tendenciát követ a fejlett országok között, ahol az urbanizáció magas és az urbanizáció sebessége lassul [26]. Jelenleg mintegy 360 millió ember, az EU teljes népességének 72\%-a él városokban és külvárosokban. Európa kivételes, hiszen városi lakosainak 2/3-a kevesebb, mint 500000 ezer lakosú városi központokban él. Kevesebb, mint 
1/10-e (7\%) 5 millió lakosú vagy nagyobb városokban él, ez az arány az Egyesült Államokban 25\% [27] [24].

\section{Vidéki élet versus egészséges életmód}

Számtalan egészségdefiníciót ismerünk, döntő többségük valamilyen egészségnorma köré szerveződik. Ezek a meghatározások nemcsak ismeretelméleti szempontból bírnak jelentőséggel, hanem praktikus következményekkel is járnak a tekintetben, hogy milyen eszközöket tartunk megfelelőnek, hatékonynak az egészségi állapot befolyásolása, fenntartása, illetve fejlesztése szempontjából. Az egészség fogalmára az is jellemző, hogy az elmúlt több mint ötven évben bővült és módosult, miképpen az Egészségügyi Világszervezet (World Health Organization) rövid áttekintésében ez bemutatásra kerül. Az egészség felfogható a testi, lelki és szociális jólét állapotaként, mint ahogyan a WHO 1946-ban rögzítette ezt [28] (4. ábra). A jelen részben kitértem a fogyasztási szokásokra, jövedelmek változásnak alakulására, a társas élet színtereire, illetve a szabadidő eltöltésére.

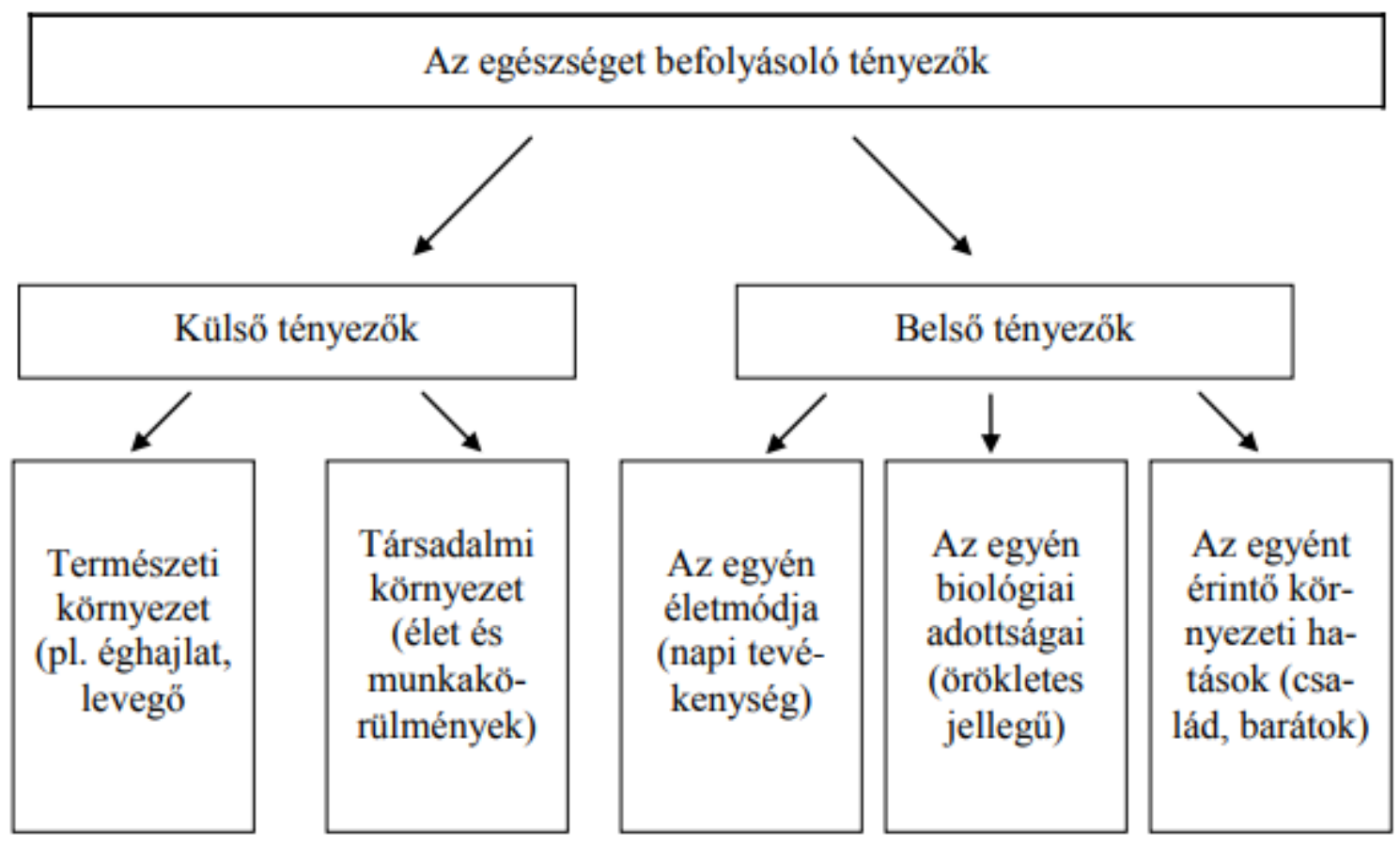

4. ábra: Az egészséget befolyásoló tényezők

Forrás: [29]

Egy példát említenék: sok olyan kisváros van ahol található színház, többnyire egy, ezzel szemben a nagyvárosokban a több színház minőségi javulást is jelenthet. Az, hogy a kisvárosokban nyugodtabb az életforma folytatható, nem minden tekintetben igaz [30].

\subsection{Fogyasztási szokások}

A városi és vidéki életmód közötti különbség fogyasztási szokások közötti eltéréseket is eredményez. Amíg vidéken korlátozottabbak a lehetőségek, addig a városban az emberek sok 
mindenhez könnyen hozzájuthatnak. A vidéken lakók időről időre a nagyvárosok peremvidékén található bevásárlóközpontokba járnak nagy tételben beszerezni azokat a termékeket, amiket a nagyvárosi életformában élők könnyen beszereznek [31] [30].

\subsection{Jövedelmeket vizsgálva}

\section{Az egy före jutó éves nettó jövedelmek alakulása, ezer forint}

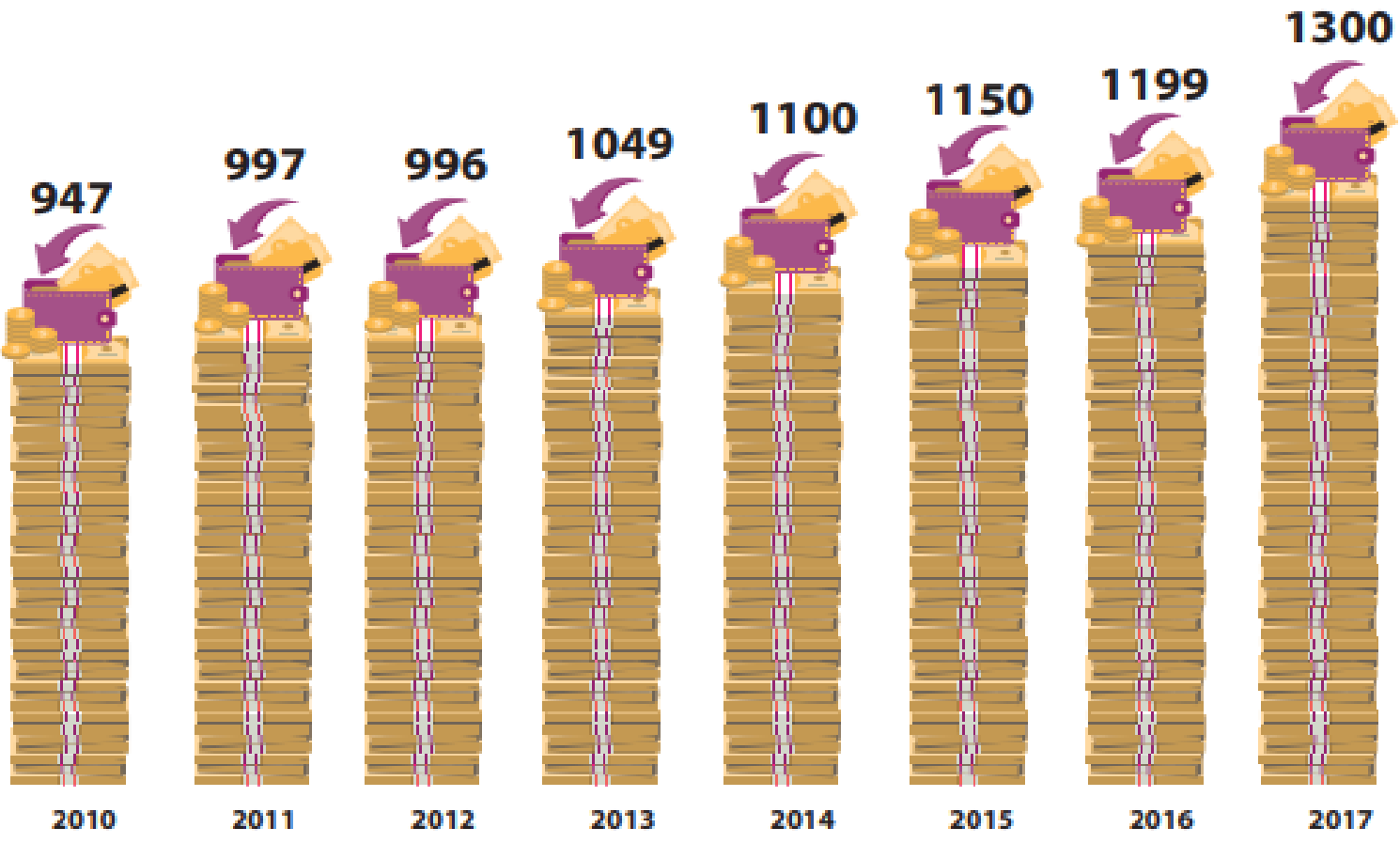

5. ábra: Az egy före jutó éves nettó jövedelmek alakulása (ezer Ft)

Forrás: [4] alapján

A háztartások jövedelmi helyzetét (lásd 5. ábra) számos makrogazdasági tényező befolyásolja, közülük is leginkább meghatározó tényezők a gazdaság teljesítőképessége, az árszínvonal és a foglalkoztatás. A 2008-as gazdasági válság évekre visszavetette a reálbérek növekedési ütemét. A háztartások jövedelmi helyzetének érezhető javulása csak 2013-ban kezdődött el. Az egy főre jutó nettó jövedelem nominálértéken 2013 és 2017 között összesen 23,9\%-kal növekedett. 2017-ben az egy főre jutó éves bruttó jövedelem 1 millió 644 ezer forint volt, 9,3\%-kal magasabb, mint az előző évben, a nettó jövedelem pedig 1 millió 300 ezer forintot tett ki, ami 8,4\%-kal haladta meg az egy évvel korábbit. A reáljövedelem 5,9\%-kal nőtt 2016-hoz képest (5. ábra) [4]. 


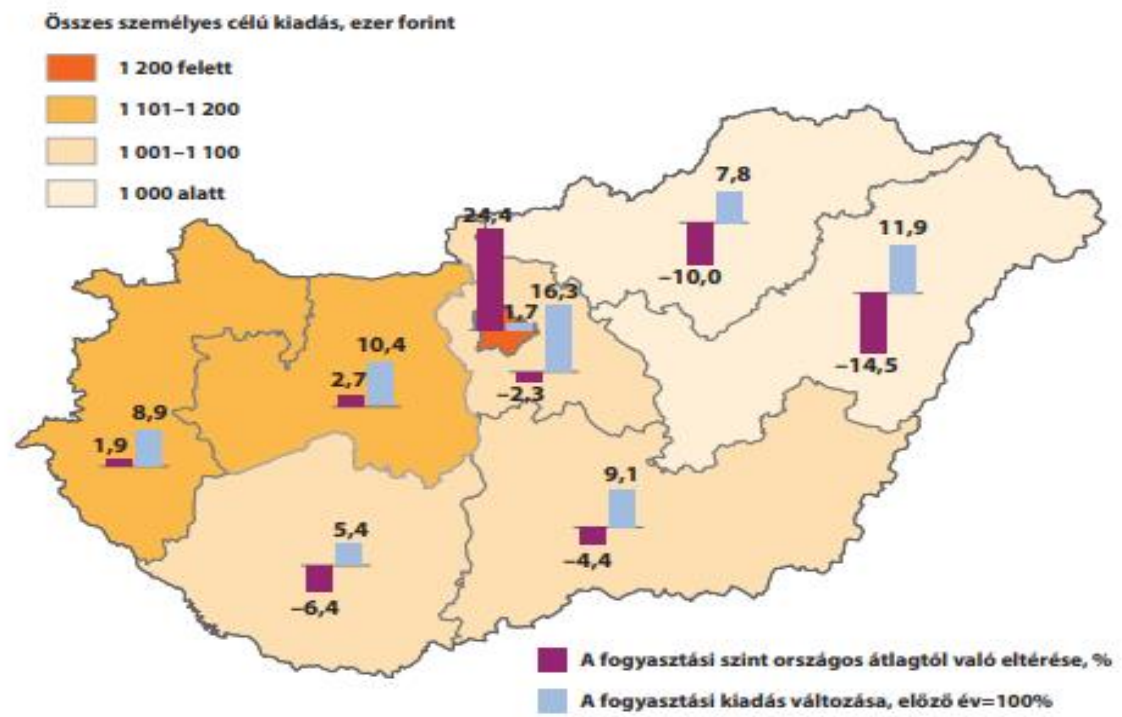

6. ábra: A háztartások egy före jutó éves átlagos fogyasztási kiadásai régiónként (ezer Ft)

Forrás: [4] alapján

Településtípusonként vizsgálva a kiadás nagyságát, Budapest dominanciája érvényesül (6. ábra), ahol az 1 millió 376 ezer forintos, egy főre jutó éves fogyasztási kiadás az országos átlagot 24,4\%kal meghaladta. A települési lejtőn lefelé haladva folyamatosan csökken a fogyasztás, ami a megyeszékhelyeken és a többi vidéki városban 1 millió 196 ezer, a vidéki városokban 1 millió 33 ezer forintot tett ki. Az egy főre jutó éves összeg a községekben volt a legalacsonyabb, 972,6 ezer forint, ami az országos átlag 87,9\%-a. Régiónként vizsgálva 2017-ben az előző évhez képest a Közép-magyarországi régióban nőtt legdinamikusabban (16,3\%-kal) a fogyasztás, ahol a kimagasló növekedés ellenére a fogyasztás színvonala az országos átlagtól még mindig 2,3\%-kal elmaradt. A kiadás növekedésének mértéke a Közép-magyarországi régiót követően ÉszakAlföldön (11,9\%), Közép-Dunántúlon $(10,4 \%)$ és Dél-Alföldön $(9,1 \%)$ volt a legmagasabb. A jelentős növekedéssel a két alföldi régió fogyasztása ugyan felzárkózást mutat, de még mindig elmarad az átlagostól, a legmarkánsabban Észak-Alföldön, ahol a fogyasztási kiadás az országos átlag mindössze 85,5\%-át tette ki. Átlag körül fogyasztottak Közép- és Nyugat-Dunántúl lakosai, és jóval átlag felett $(124,4 \%)$ a budapesti háztartások (6. ábra) [4].

\subsection{A társas élet színterei}

A vidéki és a városi társas érintkezéseket meghatározzák azok a színterek, ahol ezek lezajlanak. Megfigyelhető, hogy az emberek metakommunikációja más köztereken, boltokban, tömegközlekedési eszközön, vidéken és nagyvárosban. Jó példa lehet erre, hogy Budapesten vagy Debrecenben a tömegközlekedési eszközökön egy egyórás utazás során sokkal több emberrel találkozik egy-egy utas, mint egy kisebb település összelakossága. Természetesen az út során látott emberekkel nem alakul ki közvetlen interakció, ez megváltoztatja az ilyesfajta viszonyt a kisvárosi köztéri viselkedéshez képest [30]. 


\subsection{A szabadidő eltöltése}

Manapság a városi és a vidéki életmód közötti különbségek javarészt lecsökkentek. Egyik oldalról a vidékiek is egyre inkább hozzájutnak azokhoz a szabadidő eltöltési formákhoz, mint a városiak, másrészt a városokban élők is egyre gyakrabban töltik szabadidejüket a városokon kívül (hegyi túrák, várak látogatása, falusi turizmus). Ez mindenesetre egy tendencia, különbségek ma is adódnak. A televíziózás, mint egyik legfőbb szabadidős tevékenység, mindkét életmódot nagyban meghatározza [30].

A vidék gyorsan változik, azonban az eredeti funkciók, amelyeket a vidéki területek és a vidéken élők teljesítettek, továbbra is léteznek és működnek. Ezek mellett azonban számos új funkció jelent meg. Manapság a vidéket nemcsak mezőgazdasági termelésre, hanem rekreációs és szabadidős tevékenységekre is használják. A vidék a kényelmet és az életet szolgáló helyként funkcionál [32]. A vidékfejlesztési lehetőségek elsősorban az egyes vidéki térségek belső forrásaitól függenek. A területek fejlesztésének módja a helyben elérhető humántőkétől, gazdasági tőkétől, társadalmi tőkétől, természeti tőkétől és a helyi népesség fejlettségi szintjét befolyásoló fizikai tőkétől függ [33].

Jelenleg a városi és a vidéki életmód közötti különbségek egyre csökkennek. Egyrészt a vidéki emberek egyre inkább képesek élvezni a szabadidős tevékenységeket ugyanúgy, mint a városi emberek, másrészt egyre több városi ember tölti szabadidejét a városokon kívül. Fontos azonban megjegyezni, hogy még azokban az országokban is, ahol a lakosság nagy része vidéki területeken él, az erőforrások a városokban koncentrálódnak [18]. Az Európai Unió létrehozásával a városok és a vidék közötti kapcsolat is úgy tűnik, hogy megváltozik, mivel a nemzetgazdaságban jelentős szerepet játszó szolgáltató szektor városi környezetben működik. Az egységes piac működésében rejlő központosítási tendenciák tovább erősítik a városokat, míg a mezőgazdaság átalakulása és az elnéptelenedési tendenciák egyértelműen gyengítik a vidéki területeket [34]. Noha az utóbbi években növekedett a vidéki területek iránti érdeklődés, azok eredményei és problémái, a lezajlott kutatások terjedelme még mindig nem éri el a városi területekre vonatkozó elemzések mélységét [35].

\section{Kihívások, kockázatok}

Az ázsiai országok, elsősorban Kína és India urbanizációjával kapcsolatban számos tanulmány felhívja a figyelmet arra, hogy milyen kihívásokat, kockázatokat, veszélyeket rejt magában a nem megfelelően koordinált városnövekedés: a városi környezetszennyezés (levegőszennyezés, vízszennyezés, nem megfelelő közműhálózati kiépítettség stb.) sok esetben komoly egészségügyi kockázatot jelent [36] [37].

A robbanásszerü, koordinálatlan növekedés jelentős területhasználat-növekedéssel, a városi területek aránytalan szétterülésével is járhat, melyet mindenképpen el kell kerülni. Továbbá a jelentős mértékű városnövekedéssel együtt jár a városi szegénység növekedése is, a nyomornegyedekben élők arányának emelkedése is. Mivel a városok jelentős gazdasági potenciállal rendelkeznek és a városokban termelődik a GDP nagy része, fontos, hogy az elaprózott, széttartó urbanizáció helyett koncentrált városnövekedés menjen végbe, ezzel a 
városok erőforrás-felhasználása is relatíve alacsonyabb marad. A koncentráció mellett azonban a megavárosok speciális kihívásainak kezelésére is figyelmet kell fordítani, ezekben a városokban a nagy sűrűség miatt koncentráltan jelennek meg a fentiekben felsorolt problémák (pl. légszennyezés, infrastruktúra nem megfelelő kiépítettsége, közlekedés, lakhatás stb.) [37].

\section{Következtetés és javaslat}

A fejlődő és fejlett országok urbanizációjának eltérő tulajdonságai között az eltérő időbeli lefutást és az eltérő nagyságrendet is említhetjük [1]. A fejlett országokban ugyanis hosszú idő alatt és kevesebb embert érintve zajlott a városrobbanás szakasza, mint a fejlődőkben [2]. Városi népességnövekedés üteme az utóbbi csoportban 1950 és 1975 között 4,04\%, 1975 és 2000 között 3,6\%, 2000 és 2030 között pedig várhatóan 2,4\% lesz. Ugyanezen időpontokra a fejlett országok értékei pedig: 1,95\%, 0,83\% és 0,58\% [38]. A fejlődő országok urbanizációs tendenciájának alakulása hasonlít a fejlett országok 19. század végi, 20. század eleji értékeihez, ugyanis a fejlett országok urbanizációs rátája 1900-ban 26\% volt, 1925-re pedig 40\%-ra növekedett. A fejlődő világ ugyanezen értékeket 1975-re és 2000-re érte el [39]. A fejlődő világ urbanizációs válságának megoldása tehát egy hatalmas kihívás, ami magában foglalja nemcsak az érintett államok megfelelő gazdasági teljesítményét, hanem egy olyan politikai berendezkedést is, amely meghallgatja a szegények szavát, és a döntéshozatal során az ő érdekeit is figyelembe veszi. A Föld és az egész emberiség manapság számos kihívással néz szembe, és ez a tendencia a jövőben is folytatódni fog. A bolygó túlnépesedése és a változó étkezési szokások nagy nyomást gyakorolnak a mezőgazdaságra és a vidékre is. A vidékre összpontosító kutatások többnyire a vidéki térségek különféle funkcióinak elemzésére irányulnak.

\section{Köszönetnyilvánítás}

„Az Innovációs és Technológiai Minisztérium ÚNKP-19-3-1 kódszámú Új Nemzeti Kiválóság Programjának szakmai támogatásával készült."
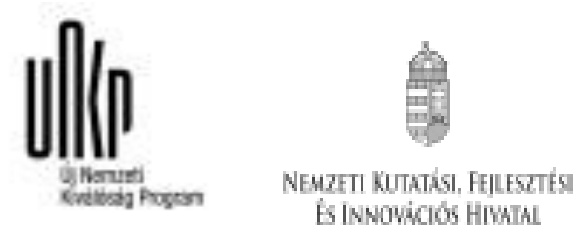

\section{Irodalomjegyzék}

[1] Ricz Judit (2009): Nyomornegyedek, szegénység, bűnözés - van-e kiút? Falu Város Régió, 2009. 2. 26-33. o

[2] Ricz Judit (2007): Urbanizáció a fejlődő országokban: trendek, dimenziók és kihívások. Tér és Társadalom, 21. 3.167-186. o.

[3] Müller A. - Bácsné Bába É. (2018): Az egészséges életmód és sport kapcsolata, Debrecen, ISBN 978-615-00-3189-7, pp. 96 o. 
[4] KSH (2018): Népesedési világnap, (letöltés dátuma: 2019. 10. 05.)

[5] World Bank (2019): Urban population,, https://www.worldbank.org/, (letöltés dátuma 2019.11.02.)

[6] United Nations (2012): World urbanization prospects: The 2011 revision, UN Department of Economic and Social Affairs, Population Division, New York.

[7] EUROSTAT (2018): Share of urban and rural populations, 1950-2050 (\% of total population), (letöltés dátuma: 2019. 11.11.)

[8] EUROSTAT (2014): 'Urban-rural typology' https://ec.europa.eu/eurostat/statisticsexplained/index.php/Archive:Urban-rural_typology

[9] P. S Golub (2010): Vándorlási szokások, http://www.magyardiplo.hu/archivum/2010- aprilis/189-avilagteljeselvarosiasodasa, (letöltés dátuma: 2019.10.12.)

[10] Kovács Zoltán (2002): Népesség- és településföldrajz. ELTE Eötvös Kiadó, Budapest, 239 o.

[11] United Nations (2017): World Population Prospects. 2017. https://www.un.org/development/desa/publications/world-population-prospectsthe-2017-revision.html

[12] WORLDHUNGER (2019): https://www.worldhunger.org/world-hunger-and-poverty facts-and-statistics/

[13] OURWORLDINDATA.ORG (2017): World Population over the last 12,000 years and UN projection until 2100. https://ourworldindata.org/grapher/world-population-17502015-and-un-projection-until-2100? country=0ur\%20World\%20In\%20Data0+UN\%20Medium\%20Variant\%20Projection\%20(2019\%20revision)0+OWID_WRL-1 (letöltés dátuma: 2019. 10.12.)

[14] FAO (2017): The future of food and agriculture - Trends and challenges. Food and Agriculture Organization of the United Nations, Rome. p.180.

[15] 'Amour, C.B. - Reitsma, F. - Baiocchi, G. - Barthel, S. - Güneralp, B. - Erb, K.-H. - Haberl, H. - Creutzig, F. - Seto, K.C. (2017): Future urban land expansion and implications for global croplands. Proceedings of the National Academy of Sciences 114, 8939-8944.

[16] Popp, J. - Lakner, Z. - Harangi-Rákos, M. - Fári, M. (2014): The effect of bioenergy expansion: food, energy, and environment. Renewable and Sustainable Energy Reviews 32, 559-578.

[17] Wheeler, T. - Von Braun, J. (2013): Climate change impacts on global food security. Science, 341, 508-513.

[18] Blum, W. E. (2005): Functions of soil for society and the environment. Reviews in Environmental Science and Bio/Technology, 4, 75-79.

[19] Fróna, D. (2018): Globális kihívások a mezőgazdaságban. International Journal of Engineering and Management Sciences, Vol. 3, No. 3. pp. 195-205. 
[20] WORLDOMETERS (2019): Current world population. https://www.worldometers.info/world-population/

[21] EASAC (2017): Opportunities and challenges for research on food and nutrition security and agriculture in Europe. EASAC Policy Report 34. German National Academy of Sciences Leopoldina, Halle. p. 80.

[22] Szenderák, J. (2018): Correlation clustering: analysis of major agricultural commodity markets. International Journal of Engineering and Management Sciences, Vol. 3, No. 3. pp. 288-302.

[23] World Urbanisation Prospects (2015): The 2014 Revision, United Nations, New York, 2015.http://esa.un.org/unpd/wup/FinalReport/WUP2014-Report.pdf p. 14

[24] PORTFOLIO (2017): Kis falvakban és túl kicsi lakásokban élünk, https://www.portfolio.hu/ingatlan/20170416/kis-falvakban-es-tul-kicsilakasokban-elunk-247599 (letöltés dátuma: 2019.11.19.)

[25] EUROSTAT (2018): Statistics on rural areas in the EU. https://ec.europa.eu/eurostat/statisticsexplained/index.php/Statistics_on_rural_areas_in_the_EU

[26] United Nations (2012): World urbanization prospects: The 2011 revision, UN Department of Economic and Social Affairs, Population Division, New York.

[27] DigitalCommons (2014): Quality of Life in Urban and Rural Europe, DUBLIN 2014, https://digitalcommons.ilr.cornell.edu/cgi/viewcontent.cgi?referer=https://www.go ogle.com/\&httpsredir=1\&article=1420\&context=intl, (letöltés dátuma 2019. 11:03.)

[28] World Health Organisation (1946): Constitution, Genova

[29] Hidvégi P. - Kopkáné P. J. - Müller A. (2015): Az egészséges életmód, Eszterházy Károly Főiskola Sporttudományi Intézet, Eger

[30] KSH (2017): Városi bizalmatlanság, vidéki bizalom. Esetleg fordítva? - A bizalom és a településtípus összefüggései Európában, Területei Statisztika, 57. szám, DOI: 10.15196/TS570404 (letöltés dátuma: 2019. 10. 25.)

[31] ALBANESE, G. - de BLASIO, G. (2014): Who Trusts others more? A cross-European study. Empirica. https://www.researchgate.net/publication/271633217_Who_trusts_ others_more_A_cross-European_study (letöltés dátuma: 2019 11.11.)

[32] Pinto-Correira, T. - Gonzalez, C. - Sutherland, L. A. - Peneva, M. (2015): Lifestyle farming: countryside consumption and transition towards new farming models. In: Sutherland, L. - Darnhofer, I. - Wilson, G. A. - Zagata, L. (eds.): Transition pathways towards sustainability in agriculture: case studies from Europe. CABI, Wallingford. pp. 67-81. 
[33] Sørensen, J. F. L. (2018): The importance of place-based, internal resources for the population development in the small rural communities. Journal of Rural Studies 59. pp. 78-87.

[34] Memagh, M. - Commins, P. (1992): Europe 2000: Meeting the Challenge of Exclusion in Peripheral Rural Areas, Poverty 3 RDU, Dublin.

[35] Jentsch, B. - Shucksmith, M. (2004): Introduction. In: Jentsch, B. - Shucksmith, M. (eds.): Young people in rural areas of Europe. Routledge, London.

[36] Dutt et al. (2004): Challenges to Asian Urbanization in the 21st Century. 2004

[37] GEOPOLITIKA (2017): Urbanizációs trendek összehasonlítása a kelet-ázsiai 6+1 ország és az Európai Unió tagállamai között http://www.geopolitika.hu/hu/2017/05/24/urbanizacios-trendekosszehasonlitasa-a-kelet-azsiai-61-orszag-es-az-europai-unio-tagallamai-kozott/, (letöltés dátuma: 2019.11.08.)

[38] World Urbanisation Prospects (2014): World Urbanization Prospect: The 2014 Revision. United Nations, Department of Economic and Social Affairs, Population Division http://esa.un.org/unpd/wup/CD-ROM/

[39] Brockerhoff, Martin - Brennan, Ellen (1998): The Poverty of Cities in Developing Regions. Population and Development Review, 24. 1. 75-114. o. 